\title{
Thomas L. Berger and Sonia Massai (eds), with Tania Demetriou. Paratexts in English Printed Drama to 1642. 2 vols. Cambridge: Cambridge Univer- sity Press, 2014. Pp xx, 614 (vol. 1); x, 430 (vol. 2).
}

HELEN SMITH

University of York
Early Theatre 19.1 (2016), 183-6

DOI: http://dx.doi.org/10.12745/et.19.1.2909

What do you call a dramatic paratext without a play? That question is either the start of a very niche joke for book historians, or a puzzle to tease the curious reader of Thomas L. Berger and Sonia Massai's two-volume compendium of Paratexts in English Printed Drama to 1642. The term 'paratext' was coined by Gerard Genette in Palimpsestes (1981) and elaborated by him in Seuils (1987; translated as Paratexts: Thresholds of Interpretation in 1997), a title that puns on the name of Genette's publisher, Éditions de Seuil, and makes richly present the interpretive force of details of publication and presentation. For Genette, the paratext consists of those features which 'surround and extend' the text proper, 'precisely in order to present it, in the usual sense of this verb but also in the strongest sense: to make present, to ensure the text's presence in the world, its "reception" and consumption in the form ... of a book'.

What Berger and Massai have gathered in these two volumes, then, are all those materials - title-pages and head titles, dedicatory epistles, addresses to the reader, commendatory poems, lists of dramatis personae, prologues, epilogues, conclusions, act and scene divisions, colophons, endnotes, and errata lists - that served to translate plays performed at the universities and on the streets, in public and private theatres, at court and in noble houses, into printed books. The editors have included neither manuscript plays nor neo-Latin drama, a venture which, they point out, would have demanded the perilous navigation of a still contested and expanding field. The structure, and much of the bibliographic description, of these two volumes follows W.W. Greg's influential A Bibliography of the English Printed Drama to the Restoration (London, 1939-59), with further details quarried from the Database of Early English Plays (DEEP). Where Greg listed plays which were part of larger collections alongside separate editions of the plays, however, Berger and Massai usefully distinguish collected editions, placing them together at the end of each volume (with collected editions to 1623 in volume 1, and later Works in volume 2). On display are the monumentalizing ambitions of such writers (and/or, as Genette would have it, of their 'allies') as William Alexander, Thomas Carew, Samuel Daniel, George Gascoigne, the now obscure Robert Gomersall, Fulke Greville, Thomas Heywood, Ben Jonson, Thomas Killigrew, 
'the onely Rare Poet of that Time, The Witie, Comicall, Facetiously-Quicke and vparalelld' John Lyly, John Marston, Thomas Middleton, Thomas Newman, Thomas Norton, Thomas Randolph, John Tatham, the various translators of Seneca, Sir Philip Sidney, and, of course, William Shakespeare.

Inevitably, some readers will quibble with what Berger and Massai have chosen to include and exclude. Prologues and epilogues which were not routinely performed on stage but preserved in or composed for print are included, but arguments, dumb shows, and choruses are generally, though not universally, omitted. Songs are included for masques but not usually for plays. Such fine distinctions highlight the difficulty of demarcating paratext from text, and demonstrate the extent to which the printed book serves at once to immerse the reader in the world of the play, and to draw attention to the artifice of both performance and print. Details of running titles (the titles at the head of the page; on this page, 'Book Reviews') are included occasionally, as for example, in the entry for John Webster's The White Devil, whose running titles direct the reader to the fate of the play's complex female protagonist, 'Vittoria Corombona'.

Perhaps the most obvious omission is of illustrations which, though the editors dutifully record them, can scarcely be captured by brief descriptions. '[Engraving of a masquer]' cannot convey the elaborate costume that accompanies Thomas Campion's The Masque at Lord Hay's Marriage (1607), whilst it would be impossible to imagine the pictures themselves from the complex descriptions of the engravings that preface Thomas Middleton's notorious A Game at Chess (1625). Perhaps ironically, the constraints of modern print mean that it is almost impossible to form a mental image of these play-texts from the assembled descriptions and transcriptions. Even the best-informed reader will be unable to pick up on subtle visual cues and the niceties of mise-en-page, including, for example, how printers' devices visually tied together disparate plays, or how the use of ornaments and printers' flowers shifted over the period.

What these volumes do give us is a cornucopia, a mass of information relating to the presentation of drama in print; the canons and corpuses of playhouses and printers; the use (and abuse) of dedications and approaches to patrons; and the ways in which plays were corrected, altered, expanded, and reflected upon during the process of publication. Paratexts, as the editors note, give us invaluable clues to how plays were to be acted, ranging from the comically common sense announcement attached to R. Wever's Lusty Juventus (1565) that 'Foure may play it easely' as long as no one attempts to play two parts at the same time, to the careful bracketing of paired parts in the smash hit Mucedorus and Amadine (1598). These volumes will also be a precious resource for students of translation, 
and of how classical authors were imagined and repackaged in early modern England. Several of these authors appear as garrulous personifications in the prefatory materials to early translations. In this context, the numerous translations of Greek and Latin material provided by Tania Demetriou are an essential resource. These collected materials also allow readers to chart debates surrounding the emergence of English as a literary language As early as 1566 Thomas Delapeend wrote in praise of his friend John Studley's translation of Agamemnon, boasting of Studley's deserved place alongside such established (if now, in some cases, largely forgotten) talents as John Heywood, Arthur Golding, Barnabe Googe, Richard Edwards, and William Neville.

Errata lists provide evidence of the difficulty of producing a correct and final print. At the end of James Shirley's The Bird in a Cage (1633), the printer concludes: 'many other Errors ... thou shalt meete, which thou canst not with safetie of thy owne, interpret a defect in the Authors Iudgment, since all bookes are subiect to these mistfortunes [sic]' (1.731). The error in the final word is, unfortunately, that of the transcribers rather than the printer; as scrupulous as Berger and Massai have been, some errors have crept in, and it would be an unwary scholar who did not return to the play to check essential details. The assembled paratexts frequently take to task the printers and booksellers who brought these plays to market, even as stationers' own estimations of the plays they publish occasionally, and fruitfully, emerge. The anonymous drama Band, Cuff, and Ruff, a lively dispute between three items of fashionable clothing, expends a great deal of paratextual energy besmirching the printer, who is supposed in turn to have besmirched the text: 'THe faults in Ruffe, Cuffe, Band, are whose, doe you thinke? The Printers? I. He spoild them with his Inke' (1.446). Though this particular complaint seems laboured in its liveliness, it points to Paratexts' further function as a treasury of energetic and inventive writing. Who could fail to be charmed by John Stephens's elaborate culinary metaphors, addressed to the reader of 'The Authors Epistle Popular' that fronts his Cynthia's Revenge (1613), which mock the increasingly stale formalities of the genre, promising not to 'discant' on the difference 'betwixt Readers, and vnderstanding Readers' or set 'formall limitiation who should, with my consent, sur-vey this Poem' (1.427).

Berger and Massai's own paratexts are slender but to the point, with a pithy introduction and essential user's guide explaining how to navigate the bibliographical conventions of each entry. The notes are functional, and though it would have been a Sisyphean task to attempt anything else, readers may sometimes wish for more detail. A very useful finding list at the end of volume 2 allows the user quickly to identify which plays feature which paratextual trappings, whilst four 
indices point users to People, Places, Plays, and Topics. This last category is the most suggestive, offering some important categories of analysis including 'Continental European models', 'copy', and 'correction', but also, inevitably, the most frustrating, given the vast range of topics that could be pulled out for consideration. So, while Martial appears in the People index, readers of the Topic index will search in vain for 'mackerel', one of his most popular bibliographic tropes. In the end, then, this is a volume not simply to be navigated through its own paratexts but to be read; even a casual browse will unearth new treasures, frequently sending readers to remarry paratext and play and explore some still-neglected early dramas. Despite the frustrations and repetitions of reading this mass of paratexts without the accompanying drama, it is a rewarding exercise, shedding light not only on the shifting shapes of the dramatic paratext but on the obsessions, the mores, the knowledge, and the habits of thought of generations of English playwrights, translators, printers, booksellers, commentators, and readers.

Sadly, Tom Berger passed away shortly after the publication of these two volumes. 'Books', he once reflected, 'are fun to hold, to smell and of course to read'. Tom's passion for print and its possibilities shines through in this project, and its encyclopaedic ambitions capture something of his generosity and joy as a scholar. Among so much else, there are many moments of sly wit and ebullient humour gathered in this volume; it is fitting that Tom was so much part of a project to share and revel in these gems.

\section{Notes}

1 Gérard Genette, Paratexts: Thresholds of Interpretation, trans. Jane E. Lewin (Cambridge, 1997), 1, http://dx.doi.org/10.1017/CBO9780511549373. 